\title{
Efek Suplemen L-Arginin Subakut Peroral pada Kontraksi Aorta Tikus Diabetes
}

\author{
Sjarif Ismail ${ }^{1 *}$, M. Mulyohadi Ali², Djoko W. Soeatmadji ${ }^{2,3}$ \\ ${ }^{1}$ Laboratorium Farmakologi Program Pendidikan Dokter, Universitas Mulawarman, Samarinda \\ ${ }^{2}$ Laboratorium Farmakologi Fakultas Kedokteran Universitas Brawijaya, Malang \\ ${ }^{3}$ Divisi Endokrin, Lab/UPF IImu Penyakit Dalam RSSA
}

\begin{abstract}
Abstrak
Penelitian ini bertujuan untuk mengetahui pengaruh suplemen L-arginin subakut peroral pada tikus diabetesstreptozotosin terhadap respons kontraksi aorta melalui mekanisme pencegahan peningkatan stress oksidatif. Larginine diberikan selama 8 minggu pada tikus diabetes dengan dosis 10,100 dan $1000 \mathrm{mg} . \mathrm{kg}^{-1} \mathrm{BB}$.hari ${ }^{-1}$. Parameter yang diukur adalah MDA-plasma untuk menilai oksidatif stress dan teknik bioassay dengan isolasi organ terpisah aorta ring untuk menilai respons reseptor adrenergik- $\alpha_{1}$ di otot polos aorta terhadap fenilefrin (PE). Dari respons kontraksi aorta dapat diketahui nilai Emaks dan $\mathrm{pD}_{2}$ PE. Hasil penelitian menunjukkan bahwa pemberian L-arginin 100, 1000 $\mathrm{mg} . \mathrm{kg}^{-1}$ BB.hari ${ }^{-1}$ pada tikus diabetes dapat mencegah peningkatan MDA-plasma $(p<0.001)$. Pemberian L-arginin dosis 100,1000 mg. kg ${ }^{-1}$ BB.hari ${ }^{-1}$ dapat mencegah peningkatan respons kontraksi aorta terhadap PE melalui pencegahan peningkatan Emaks $(p<0.000)$ dan menurunkan $\mathrm{pD}_{2}$ pada dosis $1000 \mathrm{mg} \cdot \mathrm{kg}^{-1}$ BB.hari ${ }^{-1}(p<0.001)$. Hasil Jalur Hubungan menunjukkan pencegahan peningkatan Emaks melalui jalur pencegahan peningkatan MDA $(p<0.012)$ dan penurunan $\mathrm{pD}_{2}$ melalui jalur langsung $(p<0.016)$. Berdasarkan haasil penelitian dapat disimpulkan bahwa pemberian suplemen $\mathrm{L}-$ arginin pada tikus diabetes dapat mencegah peningkatan respons kontraksi aorta terhadap PE dengan cara: (1) mencegah peningkatan Emaks melalui pencegahan peningkatan MDA (jalur tidak langsung); dan (2) secara langsung menurunkan afinitas reseptor adrenergik- $\alpha_{1}$.
\end{abstract}

Kata kunci: diabetes, L-arginin, reseptor adrenergik- $\alpha_{1}$, stress oksidatif

\section{Abstract}

This research was aimed to assess the the effect of subacute peroral L-arginine suplement on diabetes-streptozotosin rat towards the response of aorta contraction through the mechanism of prevention on the increasing oxidative stress. L-arginine was administrated for eight weeks on diabetic rats with doses 10, 100 and $1000 \mathrm{mg} . \mathrm{kg}^{-1} \mathrm{BW}$.day ${ }^{-1}$. Measured parameters are MDA-plasma to assess the oxidative stress and bioassay technique by isolate the separated organ of aorta ring. We measure the response of adrenergic- $\alpha_{1}$ receptor in aorta smooth muscle towards phenylephrine (PE). From the contraction response of aorta, we obtained the value of $E_{\max }$ and $\mathrm{pD}_{2} \mathrm{PE}$. The results showed that the administration of L-arginine $100,1000 \mathrm{mg} \cdot \mathrm{kg}^{-1} \mathrm{BW} \cdot \mathrm{day}^{-1}$ on diabetic rat prevent the increasing of MDA-plasma $(p<0.001)$. Administration of L-arginine doses $100,1000 \mathrm{mg} \cdot \mathrm{kg}^{-1} \mathrm{BW} \cdot \mathrm{day}^{-1}$ prevent the response of aorta constratcion towards $\mathrm{PE}$ through the increasing of $\mathrm{E}_{\max }(p<0.000)$ and decreasing $\mathrm{pD}_{2}$ on dose $1000 \mathrm{mg} . \mathrm{kg}^{-1} \mathrm{BW} \mathrm{day}{ }^{-1}(p<0.001)$. Pathway analysis showed the prevention of $E_{\max }$ increasing through the path of increased MDA prevention $(p<0.012)$ and decreased $\mathrm{pD}_{2}$ through direct path $(p<0.016)$. We conclude that the administration of $\mathrm{L}$-arginine supplement on diabetic to prevent the responses of aorta contraction towards PE is available in two ways: (1) prevent the increasing of $E_{\max }$ by prevent the increasing of MDA (indirect path); and (2) directly decrease the affinity of adrenergik- $\alpha_{1}$ receptor.

Kata kunci: diabetes, L-arginine, oxidative stress, receptor of adrenergic- $\alpha_{1}$

\section{PENDAHULUAN}

Berbagai penelitian telah membuktikan respons pembuluh darah tikus diabetes yang diperantarai oleh reseptor adrenergik- $\alpha$ meningkat [1-3]. Perubahan reaktifitas ini bisa

\footnotetext{
* Alamat korespondensi:

Sjarif Ismail

Alamat : Laboratorium Farmakologi Program Pendidikan Dokter, Universitas Mulawarman, Samarinda
}

merupakan efek terpisah dari kelainan fungsi endotel [4-5]. Peningkatan respons kontraksi tersebut dapat terjadi di tingkat reseptor yaitu melalui peningkatan afinitas reseptor adrenergik [3]. Peningkatan radikal bebas dapat menyebabkan peningkatan respons kontraksi pembuluh darah melalui mekanisme perubahan sinyal transduksi, yaitu meningkatkan ion kalsium sitosol otot polos pembuluh darah $[2,6]$. Jadi, pada diabetes terjadi perubahan pada sistem 
regulasi reseptor adrenergik dan sinyal transduksi untuk mempertahankan keadaan homeostasis sehingga menyebabkan perubahan pada respons kontraksi pembuluh darah.

Berbagai bukti menunjukkan peningkatan stress oksidatif pada diabetes [7-16]. Salah satu penyebab peningkatan stress oksidatif adalah penurunan L-arginin. Pada keadaan ini eNOS dapat menghasilkan superoksid selain pemben tukan NO menurun [17-19]. Beberapa penelitian telah membuktikan penurunan konsentrasi arginin plasma dan jaringan vaskular pada model hewan diabetes [21-23] dan penderita diabetes $[24,25]$. Keberadaan L-arginin yang mencukupi sangat dibutuhkan untuk mempertahankan suatu keadaan homeostasis pada diabetes. Masih belum ada penelitian efek pemberian L-arginin subakut secara oral pada tikus diabetes terhadap perubahan respons kontraksi melalui perubahan stress oksidatif. Oleh karena itu, penelitian ini bertujuan untuk mengetahui pengaruh suplemen L-arginin subakut peroral pada tikus diabetesstreptozotosin terhadap respons kontraksi aorta melalui mekanisme pencegahan peningkatan stress oksidatif.

\section{METODE PENELITIAN}

Tikus wistar jantan dari induk inbread umur 34 bulan dari Laboratorium Farmakologi FK Unibraw. Tikus dibuat diabetes dengan suntikan streptozotocine $55 \mathrm{mg} / \mathrm{kgBB}$ dalam buffer sitrat. Satu minggu setelah pemberian streptozotosine darah dari ekor tikus diperiksa dengan glukometer. Tikus dinyatakan diabetes jika gula darahnya >300 mg\% [26]. Tiap kelompok terdiri dari lima ekor tikus, yaitu tikus kontrol, diabetes, diabetes dengan perlakuan L-arginin peroral dosis 10, 100, 1000 mg.kg ${ }^{-1}$ BB.hari ${ }^{-1}$ semua diperlakukan selama 8 minggu dengan kondisi yang sama.

\section{Metode Pemeriksaan MDA-plasma.}

Digunakan plasma darah sebanyak $200 \mu \mathrm{l}$. Teknik pemeriksaan MDA-plasma disesuaikan dengan protokol yang terdapat di Laboratorium Biomedik FK Universitas Brawijaya dengan sedikit modifikasi. Pemeriksaan MDA-plasma dilakukan setelah semua sampel terkumpul semuanya, disimpan dalam lemari es $-70{ }^{\circ} \mathrm{C}$.

\section{Percobaan Organ Terpisah Aorta Ring}

Aorta yang digunakan dengan endotel intak karena dikerjakan bersama-sama dengan penelitian lain. Teknik preparasi organ terpisah aorta mengacu Pieper dan Dondlinger [23], dengan modifikasi. Aorta ring lalu potong pada cincinnya dengan panjang sekitar $3 \mathrm{~mm}$, lalu dimasukan dalam organ bath $20 \mathrm{ml}$ larutan Kreb's-Henselheit $\mathrm{pH} 7,4$ suhu $37^{\circ} \mathrm{C}$ yang dialiri gas carbogen. Salah satu ujung aorta ring dihubungkan dengan tissue holder dan ujung lainnya dipasang pada transducer isometrik (Ugo Basile No. 7004) dengan tonus 2 g dihubungkan pada komputer Macinthos LC 575, Mac Lab./8e $A D$ Instrument, Program Chard versi 3.5 buatan Michael Macknight. Setelah percobaan selesai, dihitung cross sectional area (CSA) [27]. Selanjutnya tegangan aorta diekspresikan per CSA.

\section{Respons kontraksi aorta}

Setelah ekuilibrasi tecapai, respons kontraksi aorta dengan pemberian kumulatif dosis PE. Setelah respons maksimal PE tercapai, cairan di organ bath diganti secara serial sampai kembali ke base line.

\section{HASIL}

\section{MDA-plasma terhadap pemberian L-arginin}

Hasil rerata kadar MDA akibat pemberian Larginin pada tiap kelompok tikus dapat dilihat pada tabel 1. Hasil Uji Anova didapatkan hasil yang signifikan $(p=0.000)$. Untuk mengetahui seberapa besar perbedaan rerata MDA pada tiap kelompok, dilanjutkan dengan uji Tukey.

Hasil Uji Tukey, didapatkan hasil MDA yang berbeda bermakna jika kelompok tikus A dibandingkan dengan kelompok $\mathrm{K}(0.803 \pm 0.126)$ $p=0.000$, tikus $S(0.628 \pm 0.126) p=0.001$, dan kelompok D (0.807 \pm 0.126$) \quad p=0.000$; tetapi didapatkan hasil yang tidak berbeda signifikan jika dibandingkan dengan kelompok L $(0.180 \pm$ $0.126) p=0.169$.

Hasil yang berbeda signifikan juga didapatkan jika kelompok $\mathrm{K}$ dibandingkan dengan kelompok L $(-0,623 \pm 0.126) p=0.001$, tetapi didapatkan hasil yang tidak berbeda signifikan jika dibandingkan dengan kelompok (-0.175 \pm 0.126$)$ $p=0.641$ dan kelompok $D\left(4.200 .10^{-3} \pm 0.126\right)$ $p=1.000$. Kelompok $D$ jika dibandingkan dengan kelompok $\mathrm{L}$ akan didapatkan hasil yang berbeda signifikan $(-0,627 \pm 0.126) \quad p=0.001$, tetapi didapatkan hasil yang tidak berbeda signifikan jika dibandingkan dengan kelompok S (-0.179 \pm $0.126) p=0.621$. MDA kelompok $S$ jika disbandingkan dengan kelompok $L$ didapatkan hasil yang berbeda signifikan, yaitu $(-0.448 \pm 0.126)$ $p=0.015$. Dari hasil uji regresi menunjukkan bahwa peningkatan dosis peroral L-arginin pada 
tikus diabetes dapat mempengaruhi pencegahan peningkatan MDA-plasma $\left(r^{2}=0.442, p=0.001\right)$.

Tabel 1. MDA-plasma terhadap pemberian L-arginin

\begin{tabular}{cc}
\hline Kelompok & Rerata MDA $\left(\mu \mathrm{g} \cdot \mathrm{ml}^{-1}\right)$ \\
\hline $\mathrm{K}$ & $0.194 \pm 0.039$ \\
$\mathrm{~A}$ & $0.997 \pm 0.128^{\#}$ \\
$\mathrm{~L}$ & $0.817 \pm 0.116^{\#}$ \\
$\mathrm{~S}$ & $0.369 \pm 0.069$ \\
$\mathrm{D}$ & $0.190 \pm 0.060$ \\
\hline
\end{tabular}

Keterangan:

$\mathrm{K}=$ tikus kontrol.

$A=$ tikus diabetes.

$\mathrm{L}=$ tikus diabetes $+\mathrm{L}$-arginine $10 \mathrm{mg} \cdot \mathrm{kg}^{-1} \mathrm{BB} \cdot$ hari $^{-1}$.

$\mathrm{S}=$ tikus diabetes $+\mathrm{L}$-arginine100 mg. $\mathrm{kg}^{-1} \mathrm{BB} \cdot \mathrm{hari}^{-1}$.

$\mathrm{D}=$ tikus diabetes $+\mathrm{L}$-arginine $1 \mathrm{~g} \cdot \mathrm{kg}^{-1} \mathrm{BB} \cdot \mathrm{hari}^{-1}$.

Data dinyatakan dalam mean $\pm \mathrm{SE}, \mathrm{n}=5$ ekor tikus tiap kelompok. Hasil Uji statistik berbeda sangat nyata jika $p<0.05$.

\# Berbeda sangat nyata terhadap kelompok K, S, dan D.

\section{Respons Reseptor Adrenergik- $\alpha_{1}$ terhadap Pemberian L-arginin.}

Untuk mengetahui pengaruh pemberian Larginin subakut secara oral pada tikus diabetes terhadap respons kontraksi aorta pada reseptor adrenergik- $\alpha_{1}$ maka dilakukan percobaan dengan menggunakan organ terpisah aorta. Hasil gambar rekaman kekuatan tonus kontraksi aorta terhadap pemberian fenilefrin pada tiap kelompok hewan coba di komputer McLab dalam $\mu \mathrm{V}$ seperti yang terlihat pada gambar 1 .

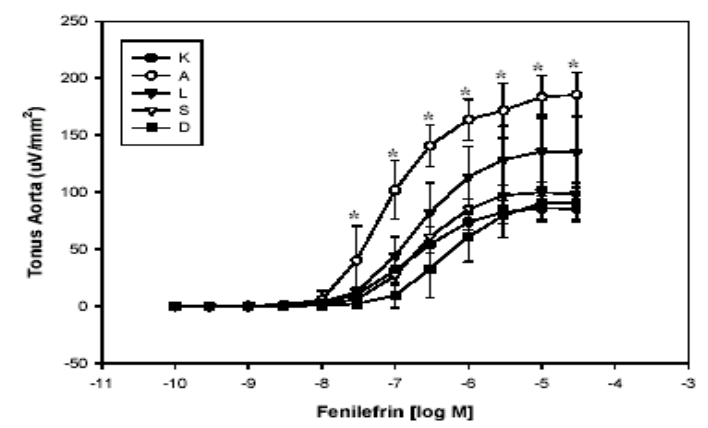

Gambar 2. Kurva dosis respons PE terhadap besarnya tonus kontraksi aorta

Keterangan:

$\mathrm{K}=$ tikus kontrol.

$A=$ tikus diabetes.

$\mathrm{L}=$ tikus diabetes $+\mathrm{L}$-arginine $10 \mathrm{mg} \cdot \mathrm{kg}^{-1} \mathrm{BB} \cdot \mathrm{hari}^{-1}$.

$\mathrm{S}=$ tikus diabetes $+\mathrm{L}$-arginine $100 \mathrm{mg} \cdot \mathrm{kg}^{-1} \mathrm{BB} \cdot$ hari $^{-1}$.

$\mathrm{D}=$ tikus diabetes $+\mathrm{L}$-arginine $1 \mathrm{~g} \cdot \mathrm{kg}^{-1} \mathrm{BB} \cdot \mathrm{hari}^{-1}$.

Hasil Uji statistik berbeda sangat nyata jika $p<0.05$.

*Berbeda sangat nyata, jika dibandingkan dengan kelompok tikus diabetes.

Pada penambahan dosis PE di organ terpisah aorta terlihat peningkatan tonus kontraksi aorta yang tergantung pada konsentrasi PE di organ bath pada semua kelompok, seperti terlihat pada gambar 2 pada bentuk kurva dosis respons PE terhadap besarnya tonus kontraksi aorta. Dari hasil Uji Anova, terlihat peningkatan kekuatan tonus kontraksi aorta pada kelompok diabetes secara bermakna jika dibandingkan kelompok lainnya, mulai bermakna pada dosis PE $\left[3.10^{-8}\right] \mathrm{M}$ $(p=0.003)$. Dengan semakin meningkatnya dosis $\mathrm{PE}$ akan semakin meningkat tonus kontraksinya.

Dari tabel 2 dapat dilihat nilai $E_{\text {maks }} P E$ dan hasil uji Anova bermakna $(p=0.000)$. Untuk mengetahui kelompok mana yang berbeda signifikan dan berapa besar perbedaan reratanya, maka dilanjutkan dengan uji Tukey. Hasilnya, nilai Emaks PE pada kelompok A mendapatkan hasil yang signifikan jika dibandingkan dengan kelompok K $(99.350 \pm 11.908)$ dengan $p=0.000$, kelompok tikus $L(49.932 \pm 11.908)$ dengan $p=0.004$, kelompok S (85.962 \pm 11.908$)$ dengan $p=0.000$, kelompok $D(92.978 \pm 11.908)$ dengan $p=0.000$.

Tabel 2. $E_{\max }$ dan $\mathrm{pD}_{2} \mathrm{PE}$ akibat pemberian L-arginin

\begin{tabular}{ccc}
\hline Kelompok & $\mathbf{E}_{\text {maks }}\left(\boldsymbol{\mu V} \mathbf{. \mathbf { m m } ^ { - 2 } )}\right.$ & $\mathbf{p D}_{\mathbf{2}}$ \\
\hline $\mathrm{K}$ & $86.45 \pm 5.07^{\#}$ & $6.83 \pm 0.10$ \\
A & $185.80 \pm 8.45$ & $7.13 \pm 0.08$ \\
L & $135.87 \pm 14.23$ & $6.78 \pm 0.12$ \\
S & $99.84 \pm 4.20^{\#}$ & $6.37 \pm 0.03$ \\
D & $92.82 \pm 6.15^{\#}$ & $6.36 \pm 0.13^{*}$ \\
\hline
\end{tabular}

Keterangan:

$\mathrm{K}=$ tikus kontrol.

$A=$ tikus diabetes

$\mathrm{L}=$ tikus diabetes $+\mathrm{L}$-arginine $10 \mathrm{mg} \cdot \mathrm{kg}^{-1} \mathrm{BB} \cdot$ hari $^{-1}$.

$\mathrm{S}=$ tikus diabetes $+\mathrm{L}$-arginine $100 \mathrm{mg} \cdot \mathrm{kg}^{-1} \mathrm{BB} \cdot$ hari $^{-1}$.

$\mathrm{D}=$ tikus diabetes $+\mathrm{L}$-arginine $1 \mathrm{~g} \cdot \mathrm{kg}^{-1} \mathrm{BB}$.hari ${ }^{-1}$.

Data dinyatakan dalam mean $\pm \mathrm{SE}, \mathrm{n}=5$ ekor tikus tiap kelompok. Hasil Uji statistik berbeda sangat nyata jika $p<0.05$.

\# Berbeda sangat nyata terhadap kelompok K, S, dan D.

Nilai $E_{\text {maks }}$ PE pada kelompok $L$ akan mendapatkan hasil yang signifikan jika dibandingkan dengan kelompok K $(49.422 \pm 11.908)$ dengan $p=0.004$, kelompok $S(36.030 \pm 11.908)$ dengan $p=0.047$, kelompok $D(43.046 \pm 11.908)$ dengan $p=0.013$. Nilai $E_{\text {maks }} P E$ pada kelompok $S$ jika dibandingkan dengan kelompok $\mathrm{K}$ dan $\mathrm{D}$ didapatkan hasil yang tidak signifikan, yaitu $(13.392 \pm 11.908)$ dengan $p=0.792$ dan $(7.016 \pm$ 11.908) dengan $p=0.975$; sedangkan kelompok $D$ jika dibandingkan dengan kelompok $\mathrm{K}$ akan didapatkan hasil yang tidak signifikan, yaitu $(6.376 \pm 11.908)$ dengan $p=0.982$. Hasil Uji regresi menunjukkan peningkatan dosis peroral Larginine pada tikus diabetes mencegah terjadinya peningkatan $E_{\text {maks }} P E\left(r^{2}=0.314, p=0.010\right)$. 
Pada gambar 3 terlihat adanya pergeseran kurva persen efek pada tikus diabetes yang diberi L-arginin. Hal ini menandakan adanya perubahan afinitas reseptor adrenergik- $\alpha_{1}$ terhadap PE. Untuk lebih jelasnya dapat dilihat dari nilai $\mathrm{pD}_{2}$ PE pada tabel 2. Dari hasil uji Anova berbeda signfikan $(p=0.000)$. Untuk mengetahui kelompok mana yang berbeda signifikan dan berapa besar perbedaan reratanya nilai $\mathrm{pD}_{2} \mathrm{PE}$, maka dilanjutkan dengan uji Tukey. Hasilnya, nilai $\mathrm{pD}_{2}$ PE kelompok A jika dibandingkan dengan kelompok $D$ didapatkan hasil yang signifikan, yaitu $(0.763 \pm 0.136)$ dengan $p=0.000$; sedangkan kelompok $A$ jika dibandingkan dengan kelompok $\mathrm{K}, \mathrm{L}, \mathrm{S}$ didapatkan hasil yang tidak signifikan, yaitu $(0.294 \pm 0.136) p=0.237,(0.345 \pm 0.136) p=0.123$ (0.396 \pm 0.136) $p=0.006$; kelompok $D$ jika dibandingkan dengan kelompok $\mathrm{K}$ dan $\mathrm{L}$ didapatkan hasil yang signifikan, yaitu $(-0.470 \pm$ $0.136) p=0.019$ dan $(-0.418 \pm 0.136) p=0.042$. Hasil uji regresi menunjukkan bahwa peningkatan dosis peroral L-arginine pada tikus diabetes dapat menurunkan $\mathrm{pD}_{2}$ PE $\left(\mathrm{r}^{2}=0.492, p=0.001\right)$.

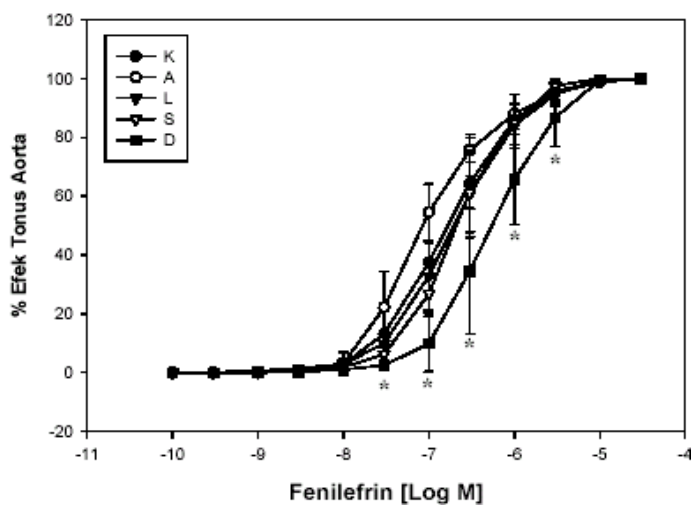

Gambar 3. Kurva dosis respons fenilefrin terhadap persen efek

Keterangan:

$\mathrm{K}=$ tikus kontrol.

$A=$ tikus diabetes.

$\mathrm{L}=$ tikus diabetes $+\mathrm{L}$-arginine $10 \mathrm{mg} \cdot \mathrm{kg}^{-1} \mathrm{BB} \cdot$ hari $^{-1}$

$\mathrm{S}=$ tikus diabetes $+\mathrm{L}$-arginine100 mg. $\mathrm{kg}^{-1} \mathrm{BB} \cdot \mathrm{hari}^{-1}$.

$\mathrm{D}=$ tikus diabetes $+\mathrm{L}$-arginine $1 \mathrm{~g} \cdot \mathrm{kg}^{-1} \mathrm{BB} \cdot$ hari $^{-1}$.

Hasil Uji statistik berbeda sangat nyata jika $p<0.05$.

* Berbeda sangat nyata jika dibandingkan dengan kelompok tikus diabetes.

\section{Model Pengaruh Dosis L-arginin terhadap $\mathrm{E}_{\text {maks }}$ dan $\mathrm{pD}_{2}$ Fenilefrin melalui MDA.}

Untuk menelusuri model pengaruh pemberian berbagai dosis arginin pada tikus diabetes terhadap $\mathrm{E}_{\text {maks }}$ dan $\mathrm{pD}_{2}$, aorta tikus pada sediaan organ terpisah melalui MDA, dilakukan analisis jalur (Path Analysis). Jadi Analisis jalur dilakukan terhadap nilai yang telah distandarkan.
Jadi analisis jalur digunakan untuk mengetahui seberapa besar pengaruh pemberian dosis arginine pada tikus diabetes terhadap $E_{\text {maks }}$ dan $\mathrm{pD}_{2}$, serta untuk mengetahui peran variable antara (MDA) terhadap perubahan $\mathrm{E}_{\text {maks }}$ dan $\mathrm{pD}_{2}$ aorta tikus seperti yang terlihat pada gambar 4 .

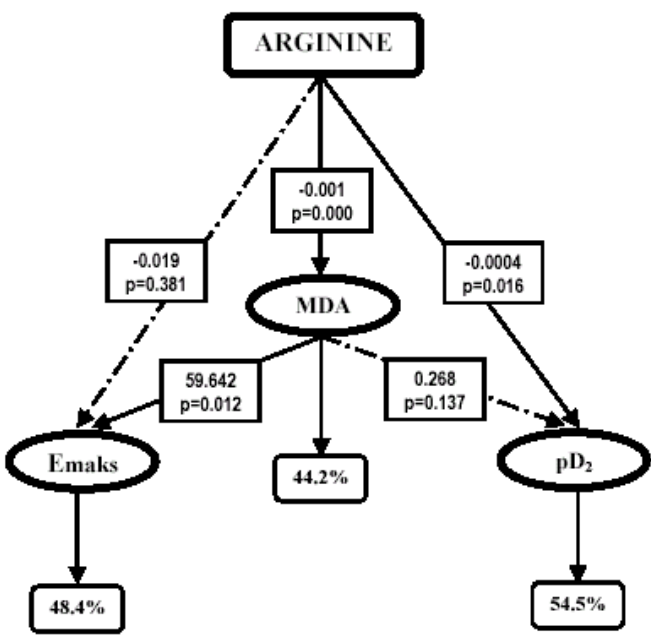

Gambar 4. Model pengaruh dosis L-arginin terhadap $E_{\text {maks }}$ dan $\mathrm{pD}_{2}$ fenilefrin melalui MDA

Keterangan:

$\rightarrow$ : Jalur dominan, jika $p<0.05$.

Dari hasil analisa jalur menunjukkan bahwa pengaruh pemberian berbagai dosis L-arginin pada tikus diabetes terhadap pencegahan peningkatan MDA besarnya $44.2 \%$, dengan koefisien jalur -0.001 dan $p=0.000$. Pengaruh pemberian berbagai dosis L-arginin peroral pada tikus diabetes dan MDA terhadap pencegahan peningkatan nilai $E_{\text {maks }} P E$ besarnya $48.4 \%$. Hubungan pemberian peroral dosis L-arginin pada tikus diabetes terhadap nilai $E_{\text {maks }} P E$ mempunyai koefisien jalur sebesar -0.019 dan $p=0.381$, sedangkan hubungan MDA terhadap nilai $E_{\text {maks }} P E$ mempunyai koefisien jalur sebesar 59.642 dan $p=0.012$. Jadi perubahan pada nilai $E_{\text {maks }} P E$ lebih dominan melalui MDA dibandingkan jalur langsung. Pengaruh pemberian berbagai dosis L-arginin peroral pada tikus diabetes dan MDA terhadap penurunan nilai $\mathrm{pD}_{2}$ PE besarnya $54.4 \%$. Hubungan pemberian peroral dosis L-arginin pada tikus diabetes terhadap nilai $\mathrm{pD}_{2}$ PE mempunyai koefisien jalur sebesar -0.0004 dan $p=0.016$, sedangkan hubungan $\mathrm{MDA}$ terhadap nilai $\mathrm{pD}_{2} \mathrm{PE}$ mempunyai koefisien jalur sebesar 0.268 dan $p=0.137$. Jadi perubahan pada nilai $\mathrm{pD}_{2}$ PE lebih dominan melalui jalur langsung. 


\section{PEMBAHASAN \\ MDA-plasma}

Pemeriksaan MDA-plasma merupakan salah satu parameter untuk membuktikan peningkatan stress oksidatif pada diabetes. Penelitian ini telah membuktikan pemberian L-arginin subakut secara oral pada tikus diabetes dapat mencegah peningkatan MDA-plasma, dimana besarnya efek pencegahan peningkatan MDA-plasma tergantung pada dosis L-arginin yang diberikan. Semakin besar dosis L-arginin yang diberikan pada tikus diabetes akan semakin besar pula mencegah terjadinya peningkatan MDA-plasma, dimana pemberian L-arginin 100 mg. $\mathrm{kg}^{-1} \mathrm{BB} \cdot$ hari $^{-1}$ pada tikus diabetes sudah terjadi keadaan MDAplasma yang tidak berbeda signifikan jika dibandingkan dengan kontrol.

\section{Stress Oksidatif}

Hasil Uji regresi menunjukan besarnya efek pencegahan peningkatan stress oksidatif pengaruh yang sigifikan dengan besarnya dosis Larginin yang diberikan $\left(r^{2}=0.442 ; p=0.001\right)$. Hal ini dapat terjadi karena salah satu mekanisme peningkatan stress oksidatif pada diabetes adalah berkurangnya substrat L-arginin di endotel sehingga terjadi keadaan yang disebut 'uncoupled eNOS', maka superoksid dihasilkan melimpah [17-20]. Berbagai bukti menunjukkan penurunan L-arginin di dalam plasma dan vaskular tikus diabetes dan penderita diabetes [21-25].

Penurunan arginin bisa disebabkan oleh: (1) kebutuhan arginin yang meningkat karena peningkatan ekspresi eNOS yang berhubungan dengan peningkatan moderate oksidasi LDL dan lisofosfatidilkolin. Peningkatan ekspresi eNOS berfungsi sebagai mekanisme pertahanan anti atero-sklerosis pada stadium awal pembentukan lesi aterosklerosis [20]; (2) penghancuran arginin yang meningkat karena: (a) pembentukan arginin-imidazolon adduct, arginin-dehidroimi dazolon adduct dan arginin-lisin croslink karena glikosilasi non-enzimatik meningkat [13], (b) katabolisme arginin yang meningkat karena overekspresi arginase [28-30]; (3) gangguan sistem transport arginin yang afinitas tinggi untuk uptake arginin ke dalam sel endotel akibat peningkatan radikal bebas [19,31-34]. Maka diperlukan upaya peningkatan L-arginin yang lebih besar dari biasanya untuk mempertahankan uptake arginin ke dalam sel endotel. Berbagai bukti telah menunjukkan bahwa pemberian Larginin peroral akan meningkatkan konsentrasi arginin dalam plasma [35]. Maka pemberian L- arginin pada tikus diabetes dapat diasumsikan meningkatkan arginin di plasma, peningkatan arginin di plasma akan meningkatkan arginin di endotel sehingga keadaan 'uncoupled' eNOS' dapat diperbaiki, hasilnya pembentukan anion superoksid berkurang. Penurunan pembentukan superoksid menyebabkan penurunan peroksidasi lipid, maka pengukuran peroksidasi lipid dengan menggunakan metoda TBA akan menghasilkan penurunan MDA-plasma. Jadi pemberian Larginin pada tikus diabetes dapat mencegah terjadinya peningkatan MDA-plasma.

Hasil Uji Regresi memperlihatkan dosis Larginin pada tikus diabetes terhadap pencegahan peningkatan MDA-plasma pengaruhnya sebesar $44.2 \%$. Hal ini dapat diartikan sebesar $65.8 \%$ tidak dapat mencegah peningkatan MDA-plasma pada diabetes dengan pemberian L-arginin. Hal ini wajar saja dapat terjadi karena 'uncoupled eNOS' tidak saja disebabkan oleh arginin yang menurun, tetapi bisa juga karena penurunan kofaktor tetrahidrobiopterin [36,37].

Selain itu, 'uncoupled eNOS' bukan satusatunya penyebab peningkatan stress oksidatif pada diabetes, masih banyak mekanisme peningkatan stress oksidatif pada diabetes yaitu: (1) meningkatnya jalur sorbitol; (2) glikosilasi non-enzimatik; (3) auto-oksidasi; (4) peningkatan PKC; (5) peningkatan siklooksigenase; (6) peningkatan angiotensin II [8-12,14-16]. Keadaan ini semua dapat menyebabkan peningkatan MDAplasma, tetapi pengaruh arginin tampaknya cukup besar dalam mencegah peningkatan MDAplasma jika dilihat dari hasil Uji Regresi.

\section{Respon Kontraksi Aorta}

Untuk mengetahui respons kontraksi aorta maka agonis yang digunakan adalah fenilefrin sebagai agonis selektif yang bekerja pada adrenergik- $\alpha_{1}$ di otot polos pembuluh darah, menyebabkan kontraksi pada otot polos pembuluh darah [38], dan menjadi pertimbangan untuk digunakan karena pada aorta tikus reseptor adrenergiknya lebih dominan adrenergik- $\alpha_{1}[39,40]$.

Berdasarkan pengamatan hasil, tampak peningkatan respons kontraksi aorta tergantung pada dosis fenilefrin di organ bath pada semua kelompok tikus. Secara umum dapat diketahui peningkatan respons kontraksi aorta diabetes dibandingkan dengan kontrol terhadap pemberian fenilefrin seperti yang terlihat pada kurva dosis respons fenilefrin terhadap besarnya tonus kontraksi aorta (gambar 2). Pada kelompok tikus 
diabetes respons kontraksi aorta lebih tinggi dibandingkan dengan kelompok kontrol, dimana mulai bermakna pada dosis fenilefrin $\left[3.10^{-8}\right] \mathrm{M}$ $(p=0.003)$. Semakin tinggi dosis fenilefrin yang diberikan akan semakin tinggi respons kontraksi aortanya dan semakin bermakna perbedaannya $(p=0.000)$. Tampak juga pemberian L-arginin pada tikus diabetes dapat mencegah peningkatan respons kontraksi aorta dan semakin besar dosis L-arginin yang diberikan akan semakin besar juga efek pencegahan peningkatan respons tersebut. Jadi pada penelitian ini terbukti pemberian Larginin subakut secara oral dapat mencegah peningkatan respons kontraksi aorta tikus diabetes.

\section{Nilai $E_{\text {maks }}$ dan $p D_{2}$ Fenilefrin}

Salah satu cara untuk mengetahui mekanisme pencegahan peningkatan respons kontraksi aorta tikus diabetes setelah diberi L-arginin subakut secara oral adalah dengan mengukur nilai $E_{\text {maks }}$ dan $\mathrm{pD}_{2}$ fenilefrin. Nilai $E_{\text {maks }}$ dapat digunakan untuk memperkirakan jumlah maksimal reseptor yang ditempati oleh agonis untuk menimbulkan efek maksimum (respons maksimum) dan juga menggambarkan mekanisme sinyal transduksinya. Besarnya efek agonis adalah proporsional dengan fraksi reseptor yang ditempati oleh agonis dan efek maksimal dihasilkan jika semua reseptor telah ditempati. Artinya efek suatu agonis berbanding lurus dengan jumlah reseptor yang ditempati dan efek suatu agonis akan mencapai maksimal jika seluruh reseptornya ditempati oleh agonis [41]. Secara fungsional reseptor terdiri dari domain ligand-binding dan domain efektor [41]. Domain ligand-binding adalah tempat interaksi antara agonis dengan reseptor, sedangkan domain efektor berinteraksi dengan berbagai molekul seluler lainnya dalam sistem sinyal transduksi.

Nilai $\mathrm{pD}_{2}$ menggambarkan afinitas agonis terhadap reseptornya atau kemampuan agonis untuk menempati 50\% reseptornya [42-43]. Bila nilai ini besar berarti afinitas reseptor terhadap agonis meningkat, artinya konsentrasi agonis yang diperlukan untuk menimbulkan respons lebih kecil sehingga dapat juga disebut sensitifitas reseptor meningkat atau dengan perkataan lain kepekaan reseptor meningkat.

Pemberian L-arginin subakut secara oral pada tikus diabetes dapat mencegah peningkatan respon kontraksi aorta terhadap fenilefrin melalui pencegahan nilai $E_{\text {maks }}$ fenilefrin. Semakin tinggi dosis L-arginin yang diberikan pada tikus diabetes akan semakin signifikan pence- gahan peningkatan nilai $E_{\text {maks }}$ fenilefrin. Pada pemberian L-arginin dosis 100 mg. kg ${ }^{-1}$ BB.hari ${ }^{-1}$ sudah mencapai suatu kondisi yang tidak berbeda bermakna jika dibandingkan dengan kontrol ( $p=0.792)$ dan diabetes $+\mathrm{L}$-arginin dosis 1 g.kg ${ }^{-1}$ BB.hari ${ }^{-1}(p=0.975)$.

\section{Regulasi Reseptor Adrenergik- $\alpha_{1}$}

Fenomena diatas secara umum bisa diasumsikan bahwa pada diabetes terjadi perubahan regulasi reseptor adrenergik- $\alpha_{1}$ kearah upregulasi reseptor adrenergik- $\alpha_{1}$ (peningkatan jumlah reseptor adrenergik- $\alpha_{1}$ ) yang diketahui dari peningkatan nilai $E_{\text {maks }}$ fenilefrin. Pemberian L-arginin secara oral pada tikus diabetes dapat diasumsikan mencegah terjadinya upregulasi/peningkatan jumlah reseptor tersebut. Mekanisme perubahan tesebut karena terjadinya regulasi reseptor untuk mempertahankan keadaan homeostasis. Jadi tidak tertutup kemungkinan upregulasi reseptor tersebut karena neuropathi pada tikus diabetes dan pemberian L-arginin dapat mencegah terjadinya neuropati. Penurunan kecepatan konduksi saraf motorik dan sensorik berhubungan dengan neuropathi pada tikus diabetes delapan minggu [44]. Adapun penelitian lain menemukan penurunan transmisi saraf neuron di prejunctional sympathethic pada tikus diabetes 12 minggu [45].

Terjadinya neuropathi pada diabetes dapat menyebabkan perubahan keseimbangan sistem saraf otonom, salah satu mekanisme tubuh untuk memperbaiki keseimbangan tersebut bisa melalui peningkatan jumlah reseptor. Hal ini dapat menjadi pertimbangkan jika melihat besarnya nilai $E_{\text {maks }}$ fenilefrin. Sedangkan pemberian L-arginin secara oral pada tikus diabetes diasumsikan dapat mencegah terjadinya neuropathi pada tikus diabetes, sehingga didapatkan nilai $E_{\text {maks }}$ fenilefrin yang tidak berbeda bermakna jika dibandingkan dengan kontrol yang dapat diartikan relatif tidak terjadi upregulasi reseptor adrenergik- $\alpha_{1}$ tetapi perlu dibuktikan lebih lanjut. Jadi tidak tertutup kemungkinan peningkatan $\mathrm{E}_{\text {maks }}$ PE pada diabetes karena upregulation reseptornya, sedangkan pemberian L-arginin pada tikus diabetes dapat mencegah upregulation pada reseptornya.

Perubahan dalam sinyal transduksi juga perlu dipikirkan karena nilai $E_{\text {maks }}$ juga menggam barkan mekanisme sinyal transduksinya. Beberapa mekanisme yang sudah diketahui adalah perubahan $\mathrm{Ca}^{2+}$ yang masuk melalui voltage- 
dependent $\mathrm{Ca}^{2+}$ channel [46] dan perubahan konsentrasi $\mathrm{Ca}^{2+}$ ekstraseluler [1]. Pada percobaan ini, peningkatan nilai $E_{\text {maks }}$ fenilefrin kemungkinan besar karena peningkatan radikal bebas. Hasil ini dipertegas dari Analisis Pathway yang menunjukkan jalur dominan pencegahan peningkatan nilai $E_{\text {maks }}$ fenilefrin melalui pencegahan peningkatan MDA-plasma (gambar 4). Karena pemberian dosis L-arginin peroral pada tikus diabetes dapat mencegah peningkatan MDA-plasma secara signifikan, sehingga berpengaruh terhadap nilai $E_{\text {maks }}$ fenilefrin secara bermakna pula.

Telah kita ketahui bahwa peningkatan radikal bebas dapat mengurangi fluiditas membran karena terjadinya peroksidasi lipid di membrannya sehingga dapat mengganggu berbagai kanal ion yang terdapat di membran. Karenanya mempengaruhi keseimbangan ion kalsium di sitosol otot polos pembuluh darah. Pemberian xanthine oksidase / hypoxanthine (menghasilkan anion superoksid) pada otot polos arteri uterine manusia kontrol akan lebih meningkatkan ion kalsium sitosol setelah pemberian noradrenalin [6]. Hal ini juga meningkatan kekuatan kontraksinya sebesar $81 \%$ seperti pada penderita diabetes dibandingkan dengan tanpa pemaparan xanthine oksidase/hypoxanthin. Sebaliknya, pemberian SOD akan meniadakan peningkatan ion kalsium dan perubahan dalam kontraksinya.

Peningkatan respons kontraksi arteri tikus diabetes disebabkan oleh peningkatan ion kalsium sitosol setelah pemberian noradrenalin dibandingkan dengan kontrol [47]. Peningkatan kontraksi arteri tikus diabetes juga dibuktikan terhadap noradrenalin karena meningkatnya influks ion kalsium ekstraseluler melalui ligan kanal kalsium [27]. Peningkatan respons kontraksi arteri mesenterika tikus diabetes terhadap noradrenalin juga dibuktikan karena peningkatan produksi inositol trifosfat [1]. Peningkatan nilai $E_{\text {maks }}$ fenilefrin tidak merubah afinitasnya, melainkan pemberian pyrogallol (menghasilkan anion superoksid) akan meningkatkan respons kontrasi aorta pada tikus diabetes dan kontrol, dimana pemberian SOD dapat mencegah peningkatan respons kontraksinya akibat pyrogallol [2].

Peningkatan $E_{\text {maks }} P E$ pada diabetes karena perubahan pada sinyal trasnduksi PKC perlu dipikirkan. Peningkatan PKC dapat meningkatkan sensitifitas protein kontraktil [48], sedangkan Kawasaki [49] membuktikan adanya peningkatan
PKC pada tikus diabetes menyebabkan peningkatan influks ion kalsium melalui kanal kalsium transmembran, selain itu harus diingat pula radikal bebas dapat juga meningkatkan PKC $[50,51]$.

Tetapi tertutup kemungkinan peningkatan $E_{\text {maks }}$ fenilefrin karena penurunan $E_{\text {maks }}$ asetilkolin, karena Dresner et al. [5] mendapatkan hasil pada tikus diabetes yang diberi L-NAME (suatu kompetitif inhibitor eNOS) dan diabetes tanpa diberi L-NAME juga mendapatkan hasil respons kontraksi arteri mesenterika yang sama peningkatannya.

Jadi pada penelitian ini telah dibuktikan pemberian L-arginin secara oral pada tikus diabetes dapat mencegah peningkatan $E_{\text {maks }}$ fenilefrin melalui mekanisme pencegahan peningkatan MDA, sehingga tidak terjadi perubahan dalam sinyal transduksinya. Tetapi tidak tertutup kemungkinan karena pencegahan upregulation reseptor adrenergik- $\alpha_{1}$.

\section{Afinitas Reseptor Adrenergik- $\alpha_{1}$}

Pada kurva dosis respons fenilefrin terhadap persen efek, tampak adanya pergeseran kurva ke kiri pada tikus diabetes. Pergeseran kurva ke kiri menandakan peningkatan afinitas reseptor adrenergik- $\alpha_{1}$. Peningkatan afinitas reseptor adrenergik- $\alpha_{1}$ pada tikus diabetes akan tampak lebih jelas jika kita membandingkannya dalam bentuk nilai $\mathrm{pD}_{2}$ fenilefrin, karena nilai $\mathrm{pD}_{2}$ menggambarkan afinitas reseptor adrenergik- $\alpha_{1}$ terhadap fenilefrin.

Pada percobaan ini ditemukan peningkatan afinitas reseptor adrenergik- $\alpha_{1}$ pada kelompok tikus diabetes tetapi tidak signifikan jika dibandingkan dengan kontrol, karena tikus diabetes yang digunakan adalah delapan minggu. Sedangkan pada penelitian Murray et al. [3] menggunakan tikus diabetes $12-15 \mathrm{mg}$. Jadi lamanya waktu juga mempengaruhi terjadinya perubahan pada afinitas reseptornya. Hasil ini sama seperti yang diperoleh Dresner et al. [5] yang mendapatkan hasil afinitas reseptor adrenergik- $\alpha_{1}$ meningkat pada kelompok tikus diabetes tapi tidak signifikan jika dibandingkan dengan kontrol. Head et al. [52] juga mendapatkan hasil yang tidak berbeda signifikan pada peningkatan afinitas reseptor tikus diabetes jika dibandingkan dengan kontrol tapi untuk noradrenarine, dimana keduanya menggunakan tikus diabetes delapan minggu.

Pemberian peroral L-arginin pada tikus diabetes selama delapan minggu terbukti dapat 
mencegah terjadinya peningkatan afinitas reseptor adrenergik- $\alpha_{1}$, semakin tinggi dosis L-arginin yang diberikan akan semakin menurunkan afinitas reseptor, tetapi penurunannya yang bermakna hanya pada pemberian L-arginin dosis 1 g.kg ${ }^{-1}$ BB.hari ${ }^{-1} \quad(p=0.000)$. Penurunan afinitas reseptor akibat pemberian L-arginin pada tikus diabetes dengan dosis 1 g. $\mathrm{kg}^{-1} \mathrm{BB} \cdot$ hari $^{-1}$ juga signifikan jika dibandingkan kontrol $(p=0.019)$. Tetapi untuk dosis 10 dan 100 mg. kg $^{-1}$ BB.hari ${ }^{-1}$ penurunannya tidak berbeda signifikan yaitu $(p=0.995)$ dan $(p=0.994)$. Fenomena ini secara umum bisa diasumsikan bahwa pada diabetes terjadi perubahan dalam regulasi reseptor adrenergik- $\alpha_{1}$ ke arah super-sensitif tetapi hasil penelitian menunjukan peningkatan nilai $\mathrm{pD}_{2}$ tidak signifikan jika dibandingkan dengan kontrol. Pemberian L-arginin pada tikus diabetes akan menyebabkan perubahan regulasi reseptor kearah desensitisasi dimana penurunan afinitas reseptor ini bermakna untuk pemberian L-arginin dosis 1 g. $\mathrm{kg}^{-1}$ BB.hari ${ }^{-1}$ jika dibandingkan dengan kelompok tikus diabetes $(p=0.000)$ dan kontrol $(p=0.019)$.

Terjadinya peningkatan afinitas reseptor pada tikus diabetes diduga juga berhubungan dengan terjadinya neuropathi, sehingga ada upaya tubuh untuk mempertahankan suatu keadaan homeostasis yang normal dengan cara meningkatkan afinitas ligand binding reseptor tersebut yang dapat dilihat pada meningkatnya nilai $\mathrm{pD}_{2}$ walaupun tidak signifikan. Pengaruh pemberian L-arginin pada tikus diabetes diperkirakan dapat mencegah terjadinya neuropathi, bahkan dosis besar ( 1 g. $\mathrm{kg}^{-1}$ BB.hari $\left.{ }^{-1}\right)$ dapat merubah regulasi reseptor tersebut kearah desensitisasi untuk mempertahankan keadaan homeostasis.

Mekanisme molekular yang terjadi untuk menerangkan hal ini masih belum diketahui, mungkin berhubungan dengan pembentukan NO yang meningkat yang dipertegas oleh Analisis Pathway. Tampak ada jalur dominan secara langsung antara dosis L-arginin dengan penurunan nilai $\mathrm{pD}_{2}$ fenilefrin. Hal ini dimungkinkan karena NO mempuyai efek biologis yang luas dalam vasoprotektif, salah satunya adalah memadamkan radikal superoksid yang banyak dihasilkan oleh tikus diabetes. Keadaan ini dimungkinkan karena interaksi antara NO dan anion superoksid sangat cepat yaitu tiga kali lebih cepat dari kecepatan reaksi superoksid dismutase (SOD) dengan anion superoksid [17, 53,54].

Bila ditinjau dari pemberian dosis L-arginin pada tikus diabetes terhadap efek pencegahan peningkatan $E_{\text {maks }}$ fenilefrin melalui MDA sebesar 48.4\%. Ini dapat diartikan 51.6\% tidak dipengaruhi oleh pemberian L-arginin. Hal ini wajar saja dapat terjadi karena mekanisme terjadinya peningkatan stress oksidatif tidak hanya disebabkan oleh penurunan L-arginin, masih banyak penyebab lainnya seperti: (1) peningkatan jalur sorbitol; (2) glikosilasi nonenzimatik; (3) auto-oksidasi; (4) peningkatan PKC; (5) peningkatan siklooksigenase; (6) peningkatan angiotensin II [8-16]. Dimana berbagai mekanisme tersebut mungkin berpengaruh pada regulasi reseptor terhadap terjadinya peningka$\tan E_{\text {maks }}$ fenilefrin. Hal yang sama juga berlaku untuk nilai $\mathrm{pD}_{2}$ fenilefrin, tetapi mungkin juga berhubungan dengan terjadinya peningkatan pembentukan NO karena adanya jalur langsung yang dominan tidak melalui MDA, maka perlu penelitian lanjutan.

Jadi pada penelitian ini telah terbukti bahwa pemberian L-arginin subakut secara oral pada tikus diabetes dapat mencegah peningkatan respons kontraksi aorta melalui mekanisme pencegahan peningkatan stress oksidatif, selain itu juga terlihat adanya jalur langsung pencegahan peningkatan respons kontraksi aorta terhadap penurunan afinitas reseptornya. Hal ini perlu dilakukan penelitian lanjutan untuk membuktikan apakah jalur langsung ini berhubungan dengan terjadinya peningkatan pembentukan NO sehingga dapat mempengaruhi regulasi reseptor ke arah desensitisasi melalui pemeriksaan isolasi organ terpisah aorta dengan endotel utuh. Selain itu juga diperlukan penelitian lanjutan pemeriksaan densitas reseptor dan sinyal transduksi lainnya karena Emaks mencerminkan jumlah reseptor yang ditempati oleh agonis dan sinyal transduksinya.

\section{KESIMPULAN}

Pemberian L-arginin 100, 1000 mg.kg ${ }^{-1}$ BB.hari ${ }^{-1}$ pada tikus diabetes dapat mencegah peningkatan MDA-plasma $(p<0.001)$. Pemberian L-arginin dosis 100, 1000 mg.kg ${ }^{-1}$ BB.hari ${ }^{-1}$ dapat mencegah peningkatan respons kontraksi aorta terhadap PE melalui pencegahan peningkatan Emaks $(p<0.000)$ dan menurunkan $\mathrm{pD}_{2}$ pada dosis 1000 mg. kg ${ }^{-1}$ BB.hari ${ }^{-1} \quad(p<0.001)$. Hasil Jalur Hubungan menunjukkan pencegahan peningkatan Emaks melalui jalur pencegahan peningkatan MDA $(p<0.012)$ dan penurunan $\mathrm{pD}_{2}$ melalui jalur langsung $(p<0.016)$.Pemberian suplemen L-arginin pada tikus diabetes dapat mencegah peningkatan respons kontraksi aorta terhadap PE dengan cara: (1) mencegah 
peningkatan $E_{\text {maks }}$ melalui pencegahan peningkatan MDA (jalur tidak langsung); dan (2) secara langsung menurunkan afinitas reseptor adrenergik- $\alpha_{1}$.

\section{UCAPAN TERIMAKASIH}

Penelitian ini dibiayai oleh Pemda TK I Kalimantan Timur dan Program Pendidikan Dokter Universitas Mulawarman. Ucapan terimakasih kepada Ka. Lab. Farmakologi DR. dr. Setyawati $S$ Karyono, MKes atas penggunaan fasilitas Laboratoriumnya, dra. Husnul Khotimah yang membantu pelaksanaan perekaman dengan komputer McLab.

\section{DAFTAR PUSTAKA}

[1] Abebe, W., K. M. MacLeod. 1992. Augmented inositol phosphate production in mesenteric arteries from diabetic rats. Eur. J. Pharmacol. 225. 29-36.

[2] Chang, K. C., S. Y. Chung, W. S. Chong, J. S. Suh, S. H. Kim, H. K. Noh, B. W. Seong, H. J. Ko, K. W. Chun. 1993. Abstrak: Possible superoxide radical-induced alteation of vascular reactivity in aortas from streptozotocin-treated rats. J. Pharmacol. Exp. Ther. 7. 992-1000.

[3] Murray, P., B. Pitt, R. C. Webb. 1994. Abstrak: Ramipril prevents hypersensitivity to phenylephrine in aorta from streptozotocin-induced diabetic rats. Diabetologia. 37. 664-70.

[4] Harris, K. H., K. M. MacLeod. 1988. Abstrak: Influence of the endothelium on contractile responses of arteries from diabetic rats. 153. 55-64.

[5] Dresner, L. S., S. P. Wang, M. W. West, I. N. Ponomarenko, C. M. Mueller, R. B. Wait. 1997. Abstrak: Nitric oxide inhibition stimulates the enhancement of alpha 1 agonist-induced vasoconstriction in diabetes. J. Surg. Res. 70. 119-23.

[6] Fleischhacker, E., V. E. Esenabhalu, M. Spitaler, S. Holzmann, F. Skrabal, B. Koidl, G. M. Kostner, W. F. Graier. 1999. Human diabetes is associated with hyperreactivitu of vascular smooth muscle cells due to altered subcellular $\mathrm{Ca}^{2+}$ distribution. Diabetes. 48. 1323-30.

[7] Tesfamarian, B., R. A. Cohen. 1992. Abstrak: Free radicals mediate endothelial cell dysfunction caused by elevated glucose. Am. J. Physiol. 263. 321-6.
[8] Griendling, K. K., C. A. Minieri, J. D. Ollerenshaw, R. W. Alexander. 1994. Abstrak: Angiotensin II stimulates NADH and NADPH oxidase activity in cultured vascular smooth muscle cells. Circ. Res. 74. 11411148.

[9] Giugliano, D., G. Paulisso, A. Ceriello. 1996. An oxidative stress and diabetic vascular complications. Diabetic Care. 19. 257-267.

[10] Ushio-Fukai, M., A. M. Zafari, T. Fukui, N. Ishizaka, K. K. Griendling. 1996. p22phox is a critical component of the superoxidegenerating NADH/NADPH oxidase system and regulates angiotensinll-induced hyperthrophy in vascular smooth muscle cells. J. Biol. Chem. 271. 23317-23321.

[11] Cohen, R. A. 1997. Endothelial dysfuction in diabetic vascular disease. Medicographia. 19. 157-161.

[12] Pagano, P. J., S. J. Chanock, D. A. Siwik, W. S. Colucci, J. K. Clark. 1998. Angiotensin II induces $p 67^{\text {phox }}$ mRNA expression and NADPH oxidase superoxide generation in rabbit aortic adventitial fibroblasts. Hypertension. 32. 331-7.

[13] Baynes, J. W., S. R. Thorpe. 1999. Perspectives in diabetes: role of oxidative stress in diabetic complications, a new perspective on an old paradigm. Diabetes. 48. 1-9.

[14] Laight, D. W., M. J. Carrier, E. E. Anggard. 2000. Antioxidant, diabetes and endothelial dysfunction. Elsevier Cardiovas. Res. 47. 457-464.

[15] Touyz, R. M., E. L. Schiffrin. 2000. Signal tranSEuction mechanisms mediating the physiological and pathophysiological actions of angiotensin II in vascular smooth muscle cells. Pharmacol. Rev. 52. 639-672.

[16] Hink, U., H. Li, H. Mollnau, M. Oelze, E. Matheis, M. Hartmann, M. Skatchkov, F. Thaiss, R. A. K. Sthal, A. Warnholtz, T. Meinertz, K. Griendling, D. G. Harrison, U. Forstermann, T. Munzel. 2001. Mechanisms underlying endothelial dysfunction in diabetes mellitus. Circ. Res. 88. 14-22.

[17] Cai, H., D. G. Harrison. 2000. Endotherial dysfunction in cardiovascular diseases: the role of oxidant stress. Circ. Res. 87. 840-844.

[18] Mather, T .J. 2000. L-arginine. In: Continuing Education Module. New Hope Institute of Retailing.

[19] Ogonowski, A. A., W. H. Kaesemeyer, L. Jin, V. Ganapathy, F. H. Leibach, R. W. Caldwell. 2000. Effects of NO donors and synthase agonist on endothelial cell uptake of L-arg 
and superoxide production. Am. J. Physiol. Cell Physiol. 278. C136-143.

[20] Govers, R., and T.J. Rabelink. 2001. Cellular regulation of endothelial nitric oxide synthase. Am. J. Physiol. Renal Physiol. 280. F193-206.

[21] Mans, A. M., R. DeJoseph, D. W. Davis, R. A. Hawkins. 1987. Abstrak: Regional amino acid transport into brain during diabetes: effect of plasma amino acids. Am. J. Physiol. 253. 575-583.

[22] Pierce, G. N., R. E. Beamish, N. S. Dhalla. 1988. Heart dysfunction in diabetes. In: Reaserch Models of Diabetes Mellitus. CRC Press Inc, Florida. 2. 23-50.

[23] Pieper, G. M., L. A. Dondlinger. 1997. Plasma and vascular tissue arginine are decreased in diabetes: acut arginine supplementation restores endotheliumdependent relaxation by augmenting CGMP production. J. Pharmacol. Exp. Ther. 283. 684-691.

[24] Hagenfeldt, L., G. Dahlquest, B. Persson. 1989. Abstrak: Plasma amino acids in relation to metabolic control in insulindependent diabetic children. Acta Pediatr. Scand. 794. 278-282.

[25] Grill, V., O. Björkman, M. Gutniak, M. Lindqvist. 1992. Abstrak: Brain uptake and release of amino acids in non diabetic and insulin-dependent diabetic subjects: important role of glutamine release for nitrogent balance. Metabolism. 41. 28-32.

[26] Nurdiana. 1993. Efek asetilkolin pada kolon tikus dengan diabetes mellitus. Tesis. Pasca Sarjana Universitas Airlangga. Surabaya.

[27] Abebe, W., Harris, K. H., Macleod, K. M., 1990. Enhanced contractile responses of arteries from diabetic rats to a1adrenoceptor stimu-lation in the absence and presence of extracellular calcium. J. Cardiovasc. Pharmacol. 16(2). 239-248.

[28] Salimudin, K. C. Upadhyaya, N. Z. Baquer, 1999. Abstrak: Effect of vanadate on expression of liver arginase in experimental diabetic rats. IUBMB Life. 48(2).

[29] Salimudin, K. C. Upadhyaya, J. Raju, N. Z. Baquer. 1999. Abstrak: Modulation of mRNA levels of liver arginase by insulin and vanadate in experimental diabetes. Indian Biochem Biophys. 36(2).

[30] Bivalacqua, T. J., W. J. Hellstrm, P. J. Kadowitz, H. C. Champion. 2001. Abstrak: Increased expression of arginase II in human diabetic corpus cavernosum: in diabetic- associated erectile dysfunction.Biochem Biophys Res Commun. 283(4).

[31] Graier, W. F., T. C. Wascher, L. Lackner, H. Toplak, G. J. Krejs, W. R. Kukovetz. 1993. Exposure to elevated D-glucose concentrations modulates vascular endothelial cell vasodilatatory response. Diabetes. 42. 14971505.

[32] Kikuta, K-I., T. Sawamura, S. Miwa, M. Hashimoto, M. Masaki. 1998. High-affinity arginine transport of bovine aortic endothelial cells is impared by lysophospha tidylcholine. Circ. Res. 83. 1088-1096.

[33] Posch, K., S. Simecek, T. C. Wascher, G. Jürgens, S. Baumgartner-Parzer, G. M. Kostner, W. F. Graier. 1999. Glycated lowdensity lipoprotein attenuates shear stressinduced nitric oxide synthesis by inhibition of shear stress-activated L-arginine uptake in endothelial cells. Diabetes. 48. 13311337.

[34] Posch, K., W F. Graier. 1999. Selective stimulation of L-arginine uptake contributes to shear stress-induced formation of nitric oxide. Life Sci. 64. 663-670.

[35] Loscalzo, J. 2000. What we know and don't know about L-arginine and NO. Circulation. 101. 2126-2129.

[36] Wever, R .M. F., T. VanDam, H. J. VanRijn, F. DeGroot, T. J. Rabelink. 1997. Abstrak: Tetrahydrobipterine regulates superoxide and nitric oxide generation by recombinant endothelial nitric oxide synthase. Biochem. Biophys. Res. Commun. 273. 340-344.

[37] Vasquez-Vivar, J., B. Kalyanaraman, P. Martasek, N. Hogg, B. S. S. Masters, H. Karoui, P. Tordo, K.A. Pritchard. 1998. Superoxide generation by endothelial nitric oxide synthase: the influence cofactor. Proc. Natl. Acad. Sci. USA. 95. 9220-9225.

[38] Lefkowitz, R. J., S. Cotecchia, P. Samama, T. Costa. 1993. Constitutive activity of receptors coupled to guanine nucleotide regulatory proteins. Trends Pharmacol. Sci. 14. 303-307.

[39] Han, C., J. Li., K. P. Minneman. 1990. Subtypes of $\alpha_{1}$-adrenoreceptor in rat blood vessel. Eur. J. Pharmacol. 190. 97-104.

[40] Aboud, R., M. Shafi, J. R. Docherty. 1993. Investigation of the subtypes of $\alpha_{1}$ adrenoreceptor mediating contraction of rat aorta, vas deferens and spleen. Br. J. Pharmacol. 109. 80-87. 
[41] Ross, E. M. 1996. Pharmacodynamics: mechanisms of drug action and the relationship between drug concentration and effect. In: Hardman, J. G., L. E. Limbird, P. B. Molinoff, R. W. Ruddon, A. G. Gilman (eds). Goodman and Gilman's: the pharmacological basis of therapeutic, editors-inchief by Ninth edition. International edition. McGraw-Hill. 2. 29-41.

[42] Ghosh, M. N. 1971. Fundamental of experimental pharmacology. Scientific Book Agency, Calcuta. 4. 16-24.

[43] Bowman, W. C., M. J. Rand. 1984. Textbook of pharmacology. Second edition. Blackwell Scientific Publication.

[44] Zochodne, D. W., V. M. K. Verge, C. Cheng, Höke, C. Joley, K. Thomsen, I. Rubin, M. Lauritzen. 2000. Nitric oxide synthase activity and expression in experimental diabetic neuropathy. J. Neuropatho. Exp. Neuro. 59. 798-807.

[45] Ralevic, V., A. Belai, G. Burnstock. 1995. Abstrak: Effects of streptozotocin-diabetes on sympathetic nerve, endothelial and smooth muscle function in the rat mesenteric arterial bed. Eur. J. Pharmacol. 14. 286. 193-199.

[46] Zhu, B. H., Y. Y. Guan, J. Min, H. He. 2001. Abstrak: Contractile responses of diabetic rat aorta to phenylephrine at different stages of diabetic duration. Acta Pharmacol. Sin. 22. 445-449.

[47] Chow, W. L., L. Zhang, K. M. MacLeod. 2001. Noradrenalin-induced changes in intracellular $\mathrm{Ca}^{2+}$ and tension in mesenteric arteries from diabetic rats. Br. J. Pharmacol. 134. 179-187.

[48] Meier, M., G. L. King. 2000. Protein kinase C. In: LeRoith, D., S. I. Taylor, J. M. Olefsky (eds). Diabetes mellitus: a fundamental and clinical text. Second edition. Lippincott Williams and Wilkins. 102. 1016-1027.

[49] Kawasaki, H. 1997. Abstrak: Pharmacological studies on alterations in contractile reactivity in aortas isolated from experimental diabetic rats. Hokkaido Igaku Zasshi. 72. 649-565.

[50] Konishi, H., M. Tanaka, Y. Takemura, H. Matzusaki, Y. Ono, U. Kikkawa, Y. Nishizuka. 1997. Activation of protein kinase $C$ by tyrosine phosphorylation in response to $\mathrm{H}_{2} \mathrm{O}_{2}$. Proc. Natl. Acad. Sci. USA. 94. 1123311237.
[51] Drödge, W. 2001. Free radicals in the physiological control of cell function. Physiol Rev. 82. 47-95.

[52] Head, R. J., P. A. Longhurst, R. L. Panek, R. E. Stizel. 1987. Abstrak: A contrasting effect of the diabetic state upon the contractile responses of aortic preparations from the rat and rabbit. Br. J. Pharmacol. 91. 275286.

[53] Wolin, M.S. 2000. Interactions of oxidants with vascular signaling systems. Arterioscler. Thromb. Vasc. Biol. 20. 140-142.

[54] Harrison, D. G. 1997. Endothelial function and oxidant stress. Clin. Cardiol. 20. 11-17. 